\title{
Faktor-Faktor yang Memengaruhi Optimalisasi Penangkapan Ikan dengan Metode Transformasi Box Cox pada Regresi Linier Berganda
}

\section{Factors Affecting Optimization of Fish Landing with Transformation Box Cox of Multiple Linear Regression Method}

\author{
Fuji Rahayu Wilujeng* \\ Program Studi Teknik Industri, Universitas Bunda Mulia, Jl. Lodan Raya No. 2 Ancol, Jakarta Utara \\ 14430, Indonesia
}

Diterima: 29 Januari 2018; Direvisi: 5 Februari 2018; Disetujui: 8 Februari 2018

\begin{abstract}
ABSTRAK
Secara umum, perbandingan luas lautan dan daratan di bumi ini adalah 70 berbanding 30. Sehingga banyak potensi dari perairan yang dapat digunakan untuk memajukan kesejahteraan manusia. Pada saat ini pun, banyak negara-negara maju dari seluruh dunia yang berlomba lomba memajukan aktivitas kemaritimannya dan kebahariannya untuk kepentingan negara tersebut sehingga dari masa ke masa peran laut menjadi dominan dalam kemajuan suatu negara. Salah satu aktivitas bahari yang paling banyak dilakukan orang-orang adalah penangkapan ikan laut. Sektor kelautan dan perikanan memiliki potensi yang sangat besar untuk menjadi penggerak ekonom nasional. Di negara Indonesia pun, banyak penduduknya yang menggantungkan hidupnya pada sektor perikanan. Sehingga padapenelitian ini yang akan dibahas adalah menentukan model jumlah produksi ikan laut di Provinsi Jawa Timur dengan metode Transformasi Box-Cox pada Regresi Linier Berganda untuk mendapatkan variabel kendali yang signifikan terhadap jumlah produksi penangkapan ikan laut di Provinsi Jawa Timur. Hasil dari regresi dengan menggunakan transformasi Box Cox menunjukkan bahwa beberapa variabel antara lain jumlah nelayan, peralatan penangkapan ikan dan kapal atau motor boat penangkapan ikan sangat berpengaruh signifikan dengan nilai $R^{2} 89.3 \%$. Dengan adanya model ini, diharapkan menjadi salah satu strategi untuk memperbanyak jumlah penangkapan ikan melalui pemilihan variabel kendali yang tepat.
\end{abstract}

Kata Kunci: Analisis Regresi, Regresi Linier Berganda, Transformasi Box-Cox, Penangkapan Ikan.

\begin{abstract}
In general, the ratio of the ocean and land area on this earth is 70 to 30. Many potentials of water can be used to promote human well-being. Even today, many developed countries from all over the world are competing to advance their maritime activities and their auspices for the country's interests so that the role of the sea becomes dominant for developing of the countries. One of the most common marine activities people do is sea fishing. the marine and fisheries sector has enormous potential to become a national economist. In Indonesia, many people depend on the fisheries sector. So, in this research that will be discussed is to determine the model of the number of marine fish production in East Java Province with Box-Cox Transformation method on Multiple Linear Regression to get significant control variable on the amount of sea fish production in East Java Province. The result of regression using Box-Cox transform shows that some variables such as the number of fishermen, fishing equipment, and boat or fishing boat motor have a significant influence on $R^{2} 89.3 \%$. With this model, it is hoped to be one strategy to increase the number of fishing through the selection of appropriate control variables.
\end{abstract}

Keywords: Regression Analysis, Multiple Linear Regression. Box-Cox Transformation, Fish Landing

*e-mail: fwilujeng@bundamulia.ac.id 


\section{PENDAHULUAN}

\subsection{LatarBelakang}

Penangkapan ikan merupakan salah satu profesi yang telah lama dilakukan oleh manusia. Menurut sejarah dahulu kala manusia purba telah melakukan kegiatan penangkapan dengan menggunakan tangan kemudian profesi ini berkembang terus secara perlahan-lahan dengan menggunakan berbagai alat yang masih sangat tradisional.

Setelah ditemukannya mesin uap (steam engine) oleh James Watt pada tahun 1769 maka penangkapan ikan laut terpengaruh perkembangannya (Sudirman dan Mallawa, 2004). Mesin-mesin tersebut tidak hanya digunakan untuk menggerakkan kapal, tetapi pada tahun 1860 mesin-mesin tersebut digunakan pula untuk menarik berbagai jenis alat tangkap. Di negara Indonesia sendiri, sejatinya merupakan salah satu negara penangkap ikan yang besar. Sekitar 60\% kebutuhan protein hewani yang dikonsumsi rakyat Indonesia berasal dari ikan dan hasil perikanan lainnya. Saat ini sektor perikanan menyerap tenaga kerja langsung sebanyak 5,35 juta orang. Suatu kontribusi yang cukup signifikan bagi pembangunan ekonomi nasional.

Dari semua provinsi yang ada di Indonesia, salah satu provinsi yang memiliki potensi besar dalam penangkapan ikan laut adalah provinsi Jawa Timur. Berdasarkan survei statistik oleh BPS, provinsi Jawa Timur berada pada urutan ketiga terbanyak untuk produksi penangkapan perikanan laut. Peringkat pertama untuk produksi penangkapan ikan laut terbanyak adalah provinsi Maluku dan peringkat kedua adalah provinsi Sumatera Utara.

Provinsi Jawa Timur mempunyai potensi perikanan darat dan laut (Sudirman dan Mallawa, 2004). Sebagian besar produksi ikan laut yang dihasilkan di Provinsi Jawa Timur meliputi ikan cakalang, tongkol, layang dan ikan tuna dengan hasil produksi yang melimpah. Selain itu, banyak dari hasil laut itu yang diekspor ke luar negeri.

Ada beberapa penelitian terdahulu yang sudah pernah dilakukan, seperti penelitian yang mengkaji tentang pengaruh antara jumlah nelayan, jumlah kapal penangkapan ikan, dan jumlah alat penangkapan ikan yang berlisensi terhadap jumlah penangkapan ikan (Ghani dan Ahmad, 2010). Hasil penelitian tersebut adalah terdapat adanya pengaruh antara jumlah nelayan dan jumlah alat penangkapan ikan terhadap jumlah penangkapan ikan terhadap nelayan di Malaysia.

Penelitian lainnya bertujuan untuk mengetahui pengaruh peralatan penangkap ikan (alat penangkap ikan, jenis kapal penangkapan ikan) terhadap pendapatan nelayan di Bandar Lampung (Situmorang, 2010). Hasil yang diperolah dalam penelitiannya menyatakan bahwa ada pengaruh yang signifikan antara alat penangkap ikan, kapal penangkap ikan dengan jumlah hasil tangkapan ikan sehingga berpengaruh terhadap meningkatnya pendapatan keluarga nelayan.

Penelitian lainnya bertujuan untuk membuktikan bahwa sektor perikanan merupakan sektor unggulan sebagai kawasan minapolitan dan menemukan variabelvariabel utama yang mendorong perkembangan sektor perikanan tangkap dan budidaya (Sulistiyanti dan Wahyudi, 2015). Faktor-faktor yang memengaruhi perkembangan perikanan tangkap adalah jumlah nelayan, perahu motor temple dan perahu/kapal motor. Selain itu, peranan sub sektor perikanan berpengaruh secara signifikan pada PDRB perikanan.

Berdasarkan hasil dari penelitian terdahulu, peneliti mencoba menggabungkan beberapa variabel yang berpengaruh dari penelitian-penelitian terdahulu terhadap produktivitas jumlah penangkapan perikanan laut. Dengan beberapa variabel bebas, antara lain jumlah nelayan, kapal boat penangkapan ikan, alat penangkapan ikan, dan PDRB Provinsi Jawa Timur. Dalam penelitian ini, peneliti mencoba menggunakan metode statistika Regresi Linier Berganda dengan transformasi Box-Cox dengan pengolahan data menggunakan perangkat lunak minitab.

Berdasarkan uraian di atas, maka pada penelitian ini akan menerapkan permasalahan perikanan di Indonesia dalam bidang matematika. Dalam penelitian ini akan dibahas mengenai pemilihan variabel bebas yang tepat untuk membuat model penangkapan ikan di Provinsi Jawa Timur. 
Dalam penelitian ini, variabel responnya adalah jumlah penangkapan ikan di perairan laut $(Y)$ dan variabel bebasnya adalah jumlah nelayan $\left(X_{l}\right)$, jumlah motor boat penangkap ikan $\left(X_{2}\right)$, jumlah alat penangkapan ikan $\left(X_{3}\right)$ dan jumlah PDRB nelayan $\left(X_{4}\right)$.

\section{METODOLOGI}

Analisis regresi merupakan sebuah alat statistik yang memberikan penjelasan tentang pola hubungan (model) antara dua variabel atau lebih. Dalam analisis regresi, dikenal dua jenis variabel yaitu variabel respon disebut juga variabelterikatyaitu variabel yang keberadaannya dipengaruhi oleh variabel lainnya dan dinotasikan dengan $Y$ dan variabel bebas yaitu variabel yang tidak dipengaruhi oleh variabel lainnyadan dinotasikan dengan $X$.

\subsection{Analisis Regresi Linier Berganda}

Analisis regresi linier berganda ialah suatu alat analisis dalam ilmu statistik yang berguna untuk mengukur hubungan antara lebih dari dua peubah (Welc dan Esquerdo, 2018)

Analisis regresi sering juga disebut sebagai analisis prediksi. Karena merupakan prediksi, maka nilai prediksi tidak selalu sesuai dengan nilai riilnya, semakin kecil tingkat penyimpangan antara nilai prediksi dengan nilai riilnya, maka semakin tepat persamaan regresinya. Bentuk umum dari persamaan regresi linier berganda dapat ditulis sebagai berikut:

$\mathrm{Y}_{\mathrm{i}}=\beta_{0}+\beta_{1} \mathrm{X}_{1 \mathrm{i}}+\beta_{2} \mathrm{X}_{2 \mathrm{i}}+\ldots . .+\beta_{k} \mathrm{X}_{\mathrm{ki}}+\varepsilon_{i}$ $\mathrm{i}=1,2, \ldots, \mathrm{n} \varepsilon_{i}{ }_{\sim}^{I I D} N\left(o, \sigma^{2}\right)$

dengan:

Y : variabel respon

$\beta_{0}, \beta_{1} \ldots \ldots \beta_{k} \quad:$ parameter regresi
$\mathrm{X}_{1}, \mathrm{X}_{2} \ldots \mathrm{X}_{\mathrm{k}} \quad$ : variabel bebas

$\varepsilon_{i} \quad:$ error

$k \quad$ : banyaknya parameter.

Secara umum tabel Analisis Variansi (ANOVA) dapat dilihat pada Tabel 1.

\subsection{Transformasi Box-Cox}

Transformasi Box-Cox merupakan transformasi pangkat pada variabel respons yang dikembangkan oleh Box dan Cox, yang bertujuan untuk menormalkan data, melinearkan model regresi dan menghomogenkan varians (Fox, 2016).

.Box dan Cox mempertimbangkan kelas transformasi berparameter tunggal, yaitu $\lambda$ yang dipangkatkanpadavariabel respons $Y$, sehingga diperoleh model transformasinya $Y^{\lambda}$ dengan $\lambda$ merupakan parameter yang harus diduga.

Transformasi Box-Cox hanya diberlakukan pada variabel respons $Y$ yang bertanda positif. Prosedur utama yang dilakukan pada Transformasi Box-Cox adalah menduga parameter $\lambda$, yang dilakukan dengan nilai dan melalui persamaan $W i$ dan $V i$ melalui persamaan:

$$
\begin{gathered}
W i=\left\{\begin{array}{l}
Y^{\lambda}-1, \text { untuk } \lambda \neq 0 \\
\text { In } Y, \text { untuk } \lambda=0
\end{array}\right. \\
V i=\left\{\begin{array}{l}
\frac{W i}{Y_{\text {geo }}^{\lambda-1}, \text { untuk } \lambda \neq 0} \\
Y_{\text {geo }} \text { In } Y, \text { untuk } \lambda=0
\end{array}\right. \\
Y_{\text {geo }}=\left(Y_{1} Y_{2 \ldots . . .} Y_{n}\right)^{1 / 2}=\left(\prod_{i=1}^{n} Y i\right)^{1 / n}
\end{gathered}
$$

Pada Tabel 2, disajikan nilai $\lambda$ dan model transformasinya. 
Tabel 1.Tabel Anova

\begin{tabular}{ccccc}
\hline Sumber Variasi & df & Sum of Squares & MS & F \\
\hline Regresi & $\mathrm{p}$ & $\sum(\hat{Y}-\bar{Y})^{2}$ & $\frac{\sum(\hat{Y}-\bar{Y})^{2}}{p}$ & $\frac{\text { MS Regresi }}{\text { MS Residual }}$ \\
Residual & $\mathrm{n}-\mathrm{p}-1$ & $\sum(Y-\hat{Y})^{2}$ & $\frac{\sum(\hat{Y}-\bar{Y})^{2}}{n-p-1}$ & \\
\hline Total & $\mathrm{n}-1$ & $\sum(Y-\bar{Y})^{2}$ & \\
\hline
\end{tabular}

\section{Keterangan:}

$\widehat{Y}$ : nilai taksiran parameter $Y$

$\bar{Y}$ : nilai rata-rata parameter $\mathrm{Y}$

Tabel 2. Nilai dan Model Transformasinya

\begin{tabular}{cc}
\hline $\boldsymbol{\lambda}$ & Transformasi \\
\hline $\mathbf{- 1}$ & $1 / \mathrm{Z}_{\mathrm{t}}$ \\
\hline $\mathbf{- 0 . 5}$ & $1 / \sqrt{\mathrm{Z}_{\mathrm{t}}}$ \\
\hline $\mathbf{0}$ & In $\mathrm{Z}_{\mathrm{t}}$ \\
\hline $\mathbf{0 . 5}$ & $\sqrt{\mathrm{Z}_{\mathrm{t}}}$ \\
\hline $\mathbf{1}$ & $\mathrm{Z}_{\mathrm{t}}$ (tidak ditransformasikan) \\
\hline
\end{tabular}

\subsection{Pengujian Parameter Regresi}

Pengujian parameter dalam model regresi bertujuan untuk mengetahui apakah parameter tersebut telah menunjukkan hubungan yang nyata antara variabel bebas dan variabel respon (Welc dan Esquerdo, 2018). Terdapat dua tahap pengujian yaitu uji serentak (simultan) dan uji parsial (individu).

1) Pengujian secara serentak

Uji serentak bertujuan untuk menguji apakah antara variabel-variabel bebas $X$ dan terikat $Y$ benar-benar terdapat hubungan linier (Corder dan Foreman, 2014).

Hipotesis:

$H_{0}: \beta_{i}=0$, dimana $\mathrm{i}=1,2,3,4, \ldots \mathrm{k}$

$H_{1}$ : ada $\mathrm{i}$ dimana $\beta_{i} \neq 0$, dimana $\mathrm{i}=$

$$
1,2,3,4, \ldots \mathrm{k}
$$

dengan:

$k$ : banyaknya variabel bebas $X$

$\beta_{i}$ : parameter ke-i model regresi linier.

Statistik Uji:

$$
\mathrm{F}_{\text {hitung }}=\frac{\mathrm{MSR}}{\mathrm{MSE}}=\frac{\mathrm{SSReg} / \mathrm{k}}{\mathrm{SSRes} /(\mathrm{n}-\mathrm{k}-1)}
$$

Kriteria Pengujian:

Tolak $H_{0}$ jika $F_{\text {hitung }}>F_{\text {tabel }(\alpha, p, n-p-1) \text {. }}$
2) Uji Individu

Uji individu digunakan jika ingin mengetahui apakah jika secara terpisah, suatu variabel $X$ masih memberikan kontribusi secara signifikan terhadap variabel terikat $Y$ (Corder dan Foreman, 2014).

Hipotesis:

$H_{0}: \beta i=0$

$H_{l}: \beta i \neq 0$

dengan:

$i=0,1, \ldots, k$

$k=$ banyaknya variabel bebas $X$.

Statistik Uji:

$t_{\text {hitung }}=\frac{\hat{\beta}_{j}}{\operatorname{s.e}\left(\hat{\beta}_{j}\right)}=\frac{b_{j}}{s\left(b_{j}\right)}$

Kriteria Pengujian:

Uji parsial ini menggunakan uji- $t$, yaitu:

-jika $t_{\text {hitung }} \leq t_{\text {tabel }}$, maka terima $H_{0}$

-jika $t_{\text {hitung }}>t_{\text {tabel }}$, maka tolak $H_{0}$.

\subsection{Uji Asumsi Residual}

Karena model regresi yang dibentuk didasarkan dengan meminimumkan jumlah kuadrat error, maka residual (sisaan) yang dalam hal ini dianggap sebagai suatu kesalahan dari pengukuran harus memenuhi beberapa asumsi, diantarannya:

\section{1) Uji Identik (Heteroscedasticitas)}

Heteroskedastisitas adalah sifat residual yang mempunyai varians yang tidak homogen. Untuk mendeteksi adanya heteroskedastisitas pada residual dipakai uji $F$ yang didapat dengan meregresikan absolut dari residual dengan variabel bebas (Hyndman dan Athanasopoulos, 2014; 
Brockwell dan Davis, 2016; Montgomery, Jennings dan Kulahci, 2016).

Hipotesis:

$H_{0}: \sigma_{1}^{2}=\sigma_{2}^{2}=\sigma_{3}^{2}=\ldots \ldots \ldots . .=\sigma_{k}^{2}=\sigma^{2}$

$H_{1}$ : minimal ada satu $\sigma_{k}^{2} \neq \sigma^{2}$

Statistik uji:

$\mathrm{F}_{\text {hitung }}=\frac{\mathrm{MSR}}{\mathrm{MSE}}=\frac{\mathrm{SSReg} / \mathrm{k}}{\mathrm{SSRes} /(\mathrm{n}-\mathrm{k}-1)}$

$\mathrm{F}_{\text {tabel }}=(\alpha, \mathrm{p}, \mathrm{n}-\mathrm{p}-1)$

dengan nilai $\mathrm{MS}_{\text {regresi }}$ dan $\mathrm{MS}_{\text {error }}$ didapat dari persamaan regresi absolut residual error sebagai berikut:

$\left|\varepsilon_{\mathrm{i}}\right|=\beta_{0}+\beta_{1} \mathrm{X}_{1 \mathrm{i}}+\beta_{2} \mathrm{X}_{2 \mathrm{i}}+\ldots . .+\beta_{k} \mathrm{X}_{\mathrm{ki}}+\delta$

Kriteria pengujian:

Apabila nilai $\mathrm{F}_{\text {hitung }}<\mathrm{F}_{\text {tabel }}$ maka $\mathrm{H}_{0}$ diterima atau residual tidak terdapat heterokedastisitas.

2) Uji Asumsi Independen

Adanya autokorelasi pada error mengindikasikan bahwa ada satu atau beberapa faktor (variabel) penting yang memengaruhi variabel terikat $Y$ yang tidak dimasukkan ke dalam model regresi (Welc dan Esquerdo, 2018).

Hipotesis:

$H_{0}: \rho_{1}=\rho_{2}=\cdots=\rho_{k}=0$ (tidak ada autokorelasi)

$H_{l}$ : minimal ada satu $\rho_{k} \neq 0$ (ada autokorelasi)

Statistik uji Durbin-Watson:

$\mathrm{d}=\frac{\sum_{t-2}^{n}\left(e_{t}-e_{t-1}\right)^{2}}{\sum_{t=12}^{n}\left(e_{t}\right)^{2}}$

Kriteria pengujian :

$d<d L$ atau $d>4-d L$ : tolak $\mathrm{H}_{0}$,

$d U<d<4-d U$ : terima $\mathrm{H}_{0}$,

$d L \leq d \leq d U$ atau $4-d U \leq d \leq 4-d L$ : tak dapat disimpulkan

dengan:

$d$ : nilai statistik uji Durbin-Watson hasil perhitungan

$d L$ : batas bawah Tabel Durbin-Watson bounds pada suatu $n$ dan $k$ tertentu $d U$ : batas atas Tabel Durbin-Watson bounds pada suatu $n$ dan $k$ tertentu

$n$ : banyaknya pengamatan

$k$ : banyaknya variabel bebas dalam model regresi.

3) Uji Asumsi Distribusi Normal

Model regresi yang baik adalah memiliki nilai residual yang terdistribusi normal (Corder dan Foreman, 2014). Asumsi persyaratan normalitas harus terpenuhi untuk mengetahui apakah residual/error dari data berdistribusi normal atau untuk mengetahui apakah data sampel berasal dari populasi yang berdistribusi normal. Pengujian statistik dengan menggunakan kolmogorov-smirnov normality test. Jika model belum memenuhi asumsi normal, data dapat ditransformasi dengan menggunakan transformasi Box-Cox. Uji asumsi distribusi normal adalah untuk melihat apakah nilai residual terdistribusi normal atau tidak.

Hipotesis:

$H_{0}: \varepsilon_{i}$ berdistribusi normal

$H_{i}: \varepsilon_{i}$ berdistribusi tidak normal

Statistik uji Kolmogorov-smirnov :

$D=\operatorname{Sup}|\mathrm{S}(\mathrm{x})-\mathrm{F}(\mathrm{x})|$

dengan :

$F(x)=$ fungsi distribusi kumulatif

$S(x)=$ fungsi distribusi sampel

Kriteria pengujian :

Jika nilai $D_{\text {hitung }}<D_{\text {tabel(1-a,n) }}$ maka $H_{0}$ diterima.

4) Uji Multikolinieritas

Multikolinearitas merupakan korelasi atau hubungan yang kuat diantara variabelvariabel bebas dalam persamaan regresi linear berganda (Welc dan Esquerdo, 2018). Multikolinearitas terjadi jika nilai Variance Inflation Factor (VIF) lebih besar dari 10.

Rumus untuk mendapatkan nilai VIF adalah sebagai berikut:

$V I F=\frac{1}{1-R j^{2}}$

Jika terjadi terjadi multikolinearitas pada model, dapat diatasi dengan mengeluarkan variabel bebas yang berkorelasi tinggi. Pengeluaran variabel ini dapat dilakukan 
Tabel 3. Tabel Anova Analisis Regresi Variabel $Y$ dengan Variabel $X_{1}, X_{2}, X_{3}$ dan $X_{4}$

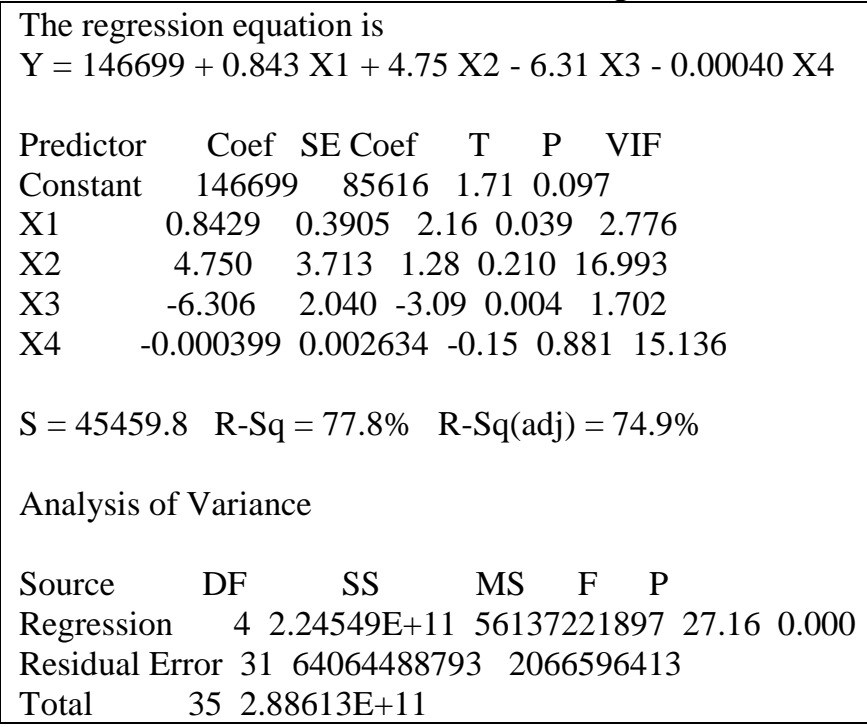

\subsection{Uji Koefisien Determinasi}

Koefisien determinasi $\left(R^{2}\right)$ adalah besarnya keragaman (informasi) di dalam variabel $\mathrm{Y}$ yang dapat diberikan oleh model regresi yang didapatkan. Koefisien ini dinyatakan dalam \% yang menyatakan kontribusi variabel bebas terhadap variabel respon. Apabila nilai $R^{2}$ dikalikan $100 \%$, maka hal ini menunjukkan persentase keragaman (informasi) di dalam variabel $\mathrm{Y}$ yang dapat diberikan. Semakin besar nilai $R^{2}$, semakin baik model regresi yang diperoleh (Fox, 2016).

\section{HASIL DAN PEMBAHASAN}

Dari hasil analisis diperoleh suatu model regresinya sebagai berikut:

$$
\begin{aligned}
& Y_{i}=146699+0,843 X_{1 i}+4,75 X_{2 i}- \\
& 6,31 X_{3 i^{-}} 0,00040 X_{4 i}+\varepsilon_{i}
\end{aligned}
$$

Setelah dilakukan pengujian parameter untuk uji serentak, pada Tabel 3 diperoleh nilai $\mathrm{F}_{\text {hitung }}=27,16>\mathrm{F}_{\text {tabel }(5 \%, 4,32)}$ $=2,67$, maka $\mathrm{H}_{0}$ ditolak yang berarti dapat disimpulkan bahwa secara bersama-sama terdapat pengaruh variabel $X_{1}, X_{2}, X_{3}$ dan $X_{4}$ terhadap variabel $Y$. Sedangkan untuk uji individu yang dapat dilihat pada Tabel 3 diperoleh nilai koefisien regresi dari masingmasing $X_{1}, X_{2}, X_{3}$, dan $X_{4}$ tidak signifikan karena nilai $t_{\text {hitung }}$ dari masing-masing koefisiennya lebih kecil daripada $t_{\text {tabel }}=$ $t_{0,05 ; 32}=2,037$, sehingga untuk variabel $X_{1}$ dan $X_{3}$, parameter regresi secara individual memberikan pengaruh yang berarti terhadap model. Sedangkan variabel $X_{2}$ dan $X_{4}$ yang bersesuaian dengan parameter regresi secara individual tidak memberikan pengaruh yang berarti terhadap model.

3.1 Uji Asumsi Residual Setelah Dilakukan Transformasi Box-Cox

1) Uji Identik (Heteroscedasticitas).

Dari hasil penghitungan pada Tabel 4 diperoleh $F_{\text {hitung }}=2,33<F_{\text {tabel }}(5 \%, 4,32)=2,67$, dengan demikian $\mathrm{H}_{0}$ diterima, maka dapat disimpulkan bahwa dalam model regresi tidak terjadi heteroskedastisitas.

Tabel 4. Tabel Anova Analisis Regresi Absolut Residual

\begin{tabular}{llllll}
$\begin{array}{l}\text { Sumber } \\
\text { Variasi }\end{array}$ & df & \multicolumn{1}{c}{ SS } & MS & F \\
\hline Regresi & 4 & 7413722 & 18534305 & 2.33 \\
\hline Residual & 31 & 2463932 & 79481696 & \\
\hline Total & 35 & 3205304 & & \\
\hline
\end{tabular}

2) Independen (Autokorelasi)

Secara umum, pengujian autokorelasi menggunakan plot ACF seperti pada Gambar 1. Jika ada lag yang keluar dari garis merah, maka dapat disimpulkan bahwa terdapat autokorelasi. 


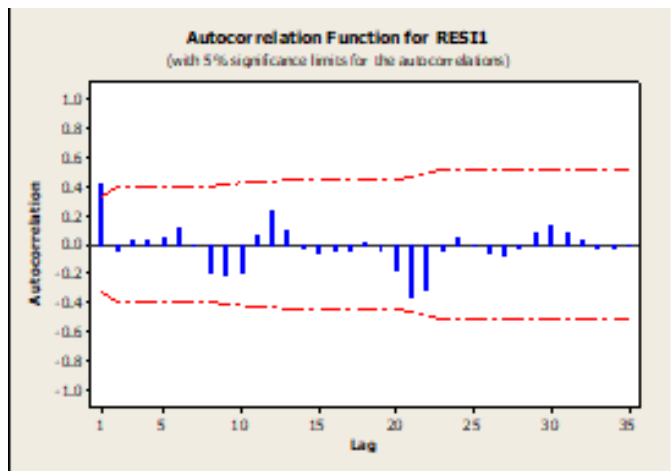

Gambar 1. Plot ACF Residual 1

3) Uji Normalitas

Hasil pengolahan minitab menggunakan test Kolmogorov Smirnov pada Gambar 2 menunjukkan $p$-value $>0,05$ sehingga sudah memenuhi asumsi normal.

\section{4) Multikolinearitas}

Dari hasil analisis regresi pada Tabel 3, multikolinearitas diperoleh dari nilai VIF yang lebih besar dari 10 yaitu variabel $X_{2}$ dan $X_{4}$, sehingga diduga ada multikolinearitas antar variabel bebas tersebut.

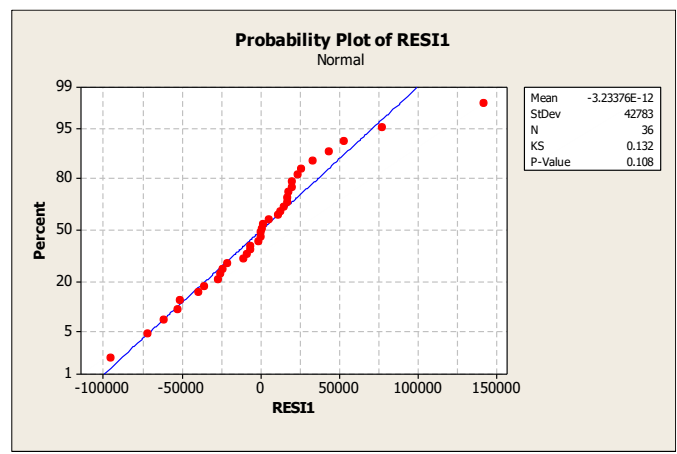

Gambar 2 Uji Normalitas Residual 1

\subsection{Perbaikan Model}

Dari model yang didapat pada persamaan (1), masih terdapat autokorelasi dan multikolenieritas. Oleh karena itu, antar variabel bebasnya perlu diadakan tinjauan ulang terhadap model tersebut dengan melakukan transformasi terhadap semua variabelnya, yaitu variabel $Y, X_{1}, X_{2}, X_{3}$ dan $X_{4}$ dengan menggunakan transformasi BoxCox. Untuk selanjutnya, semua variabel yang sudah ditransformasi diberi lambang $Y^{*}, X_{1}^{*}, X_{2}^{*}, X_{3}^{*}$ dan $X_{4}^{*}$. Variabel hasil transformasi dapat dilihat dari Gambar 3 sampai Gambar 7.

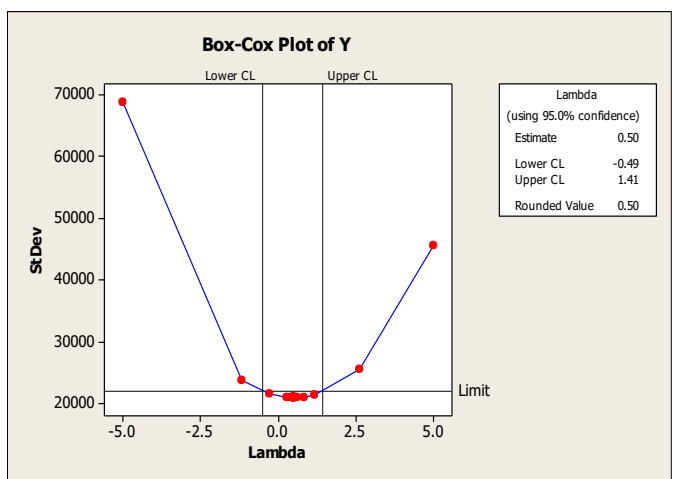

Gambar 3. Transformasi Variabel $Y$

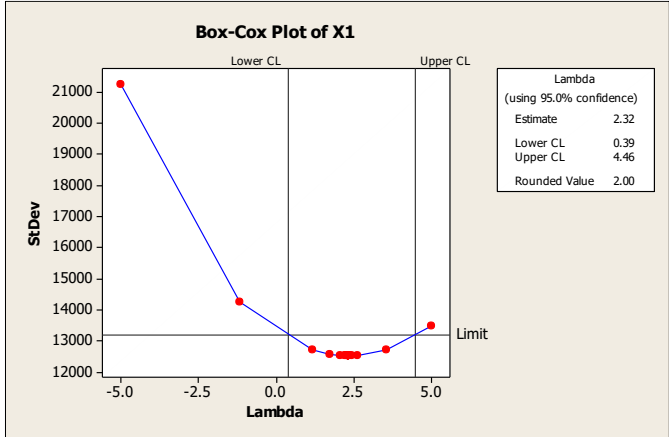

Gambar 4. Transformasi Variabel $X_{l}$

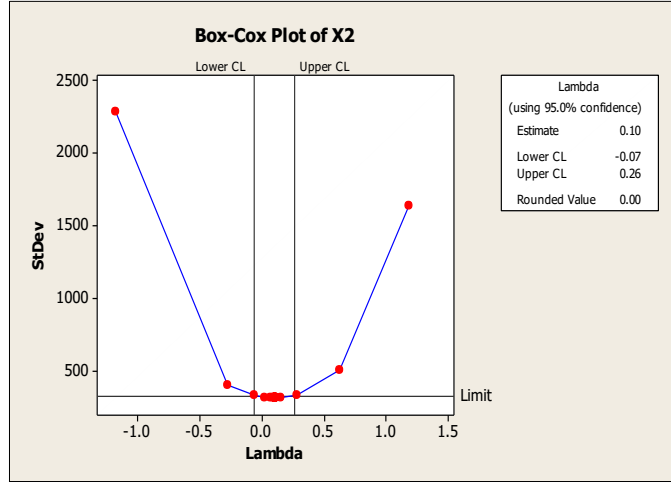

Gambar 5. Transformasi Variabel $X_{2}$

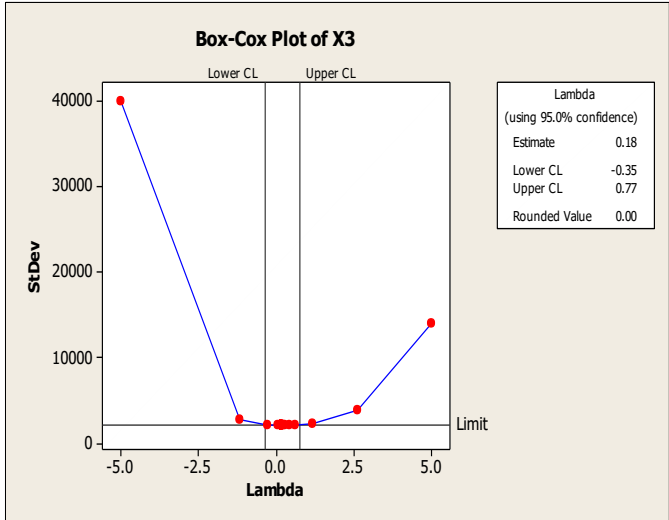

Gambar 6. Transformasi Variabel $X_{3}$ 


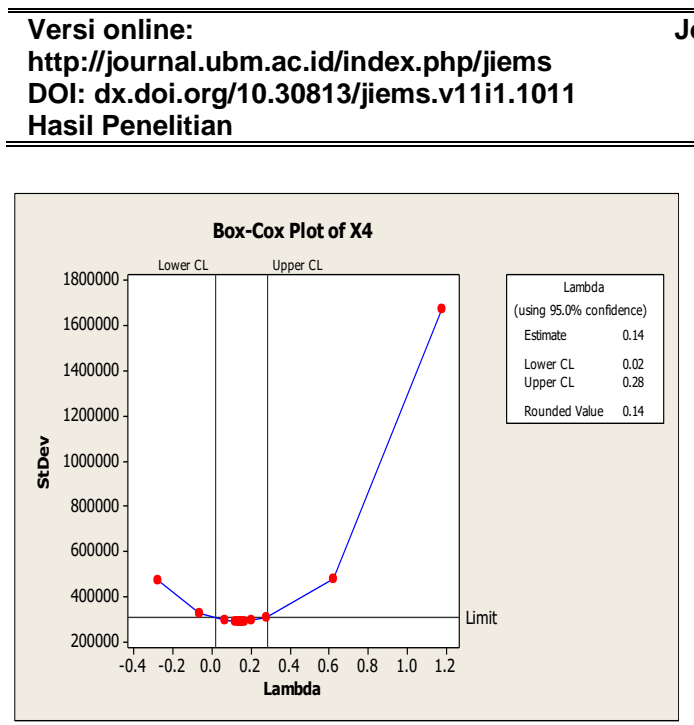

Gambar 7. Transformasi Variabel $X_{4}$

Setelah dilakukan transformasi dengan Box-Cox didapat persamaan regresinya, yaitu:

$$
\begin{aligned}
& Y^{*}=461+0.00 X 1^{*}+30.6 X 2^{*}- \\
& 23.5 X 3^{*}+6.2 X 4^{*}+\varepsilon_{\mathrm{i}}
\end{aligned}
$$

dengan:

$Y_{i}^{*}$ mempunyai nilai $\left(\mathrm{Y}_{1 \mathrm{i}}\right)^{0,5}$

$X_{1 i} *$ mempunyai nilai $\left(\mathrm{X}_{1 \mathrm{i}}\right)^{2}$

$X_{2 i} *$ mempunyai nilai In $\mathrm{X}_{2 \mathrm{i}}$

$X_{3 i} *$ mempunyai nilai In $\mathrm{X}_{3 \mathrm{i}}$

$X_{4 i} *$ mempunyai nilai $\left(\mathrm{X}_{4 \mathrm{i}}\right)^{0,14}$
Journal of Industrial Engineering and Management Systems

Vol. 11, No. 1, 7-16, 2018

ISSN 1979-1720

E-ISSN 2579-8154

Ditransformasi

\begin{tabular}{ccccc}
\hline Variabel & Koef & $\begin{array}{c}\text { SE } \\
\text { Koef }\end{array}$ & Thitung & VIP \\
\hline Constant & 460.6 & 157.5 & 2.92 & \\
\hline $\mathrm{X} 1^{*}$ & 0.000 & 0.000 & 0.02 & 3.757 \\
\hline $\mathrm{X} 2^{*}$ & 30.55 & 13.54 & 2.26 & 27.10 \\
\hline $\mathrm{X}^{*}$ & -23.45 & 14.85 & -1.58 & 2.218 \\
\hline $\mathrm{X}^{*}$ & 6.21 & 10.12 & 0.61 & 21.6 \\
\hline
\end{tabular}

Dilihat pada Tabel 5, hasil regresi setelah ditransformasi masih terdapat multikolinearitas pada variabel $X_{2} *$ dan $X_{4}$ * karena nilai VIF yang lebih besar dari 10 . Untuk mengatasi hal tesebut, maka salah satu variabel yang memiliki nilai $\mathrm{p}$ value terbesar diantara variabel yang mengalami multikoleniaritas tersebut dapat dihilangkan. Dalam kasus ini, p value untuk variabel $X_{4}$ $(p$ value $=0,544)$ lebih besar daripada $\mathrm{p}$ value untuk variabel $X_{2}(\mathrm{p}$ value $=0,031)$, maka variabel $X_{4}$ dapat dihilangkan kemudian bisa dilakukan proses regresi lagi. Hasil regresi pada Tabel 6 setelah variabel $X_{4}$ dihilangkan adalah:

$$
\begin{aligned}
& Y^{*}=420+0.000000 X 1^{*}+38.2 X 2^{*} \\
& -19.9 X 3^{*}+\varepsilon_{i}
\end{aligned}
$$

Tabel 6. Tabel Anova Analisis Regresi variabel $Y^{*}$ dengan variabel $X_{1}{ }^{*}, X_{2}{ }^{*}, X_{3} *$

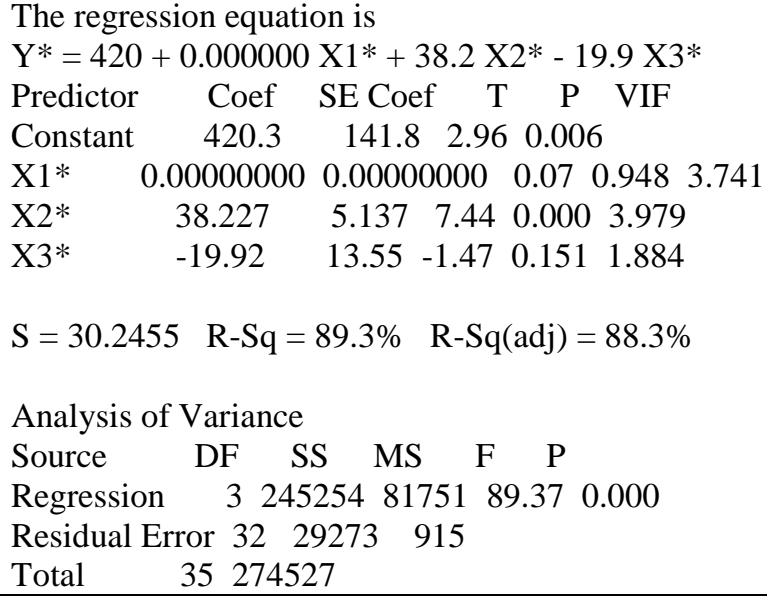




\subsection{Uji Asumsi Residual Setelah Model} Diperbaiki

Setelah mendapatkan model yang baru pada persamaan (3), maka selanjutnya dilakukan uji asumsi residual lagi. Pada uji asumsi residual terdapat empat tahap yang akan dibahas, yaitu:

1) Uji Identik (Heteroscedasticitas).

Dari hasil penghitungan pada Tabel 7 diperoleh $F_{\text {hitung }}=1.15<F_{\text {tabel }(5 \%, 4,32)}=2,67$, dengan demikian $\mathrm{H}_{\mathrm{o}}$ diterima, maka dapat disimpulkan bahwa dalam model regresi tidak terjadi heteroskedastisitas.

Tabel 7. Tabel Anova Absolut Residual Setelah Transformasi

\begin{tabular}{lllll}
\hline $\begin{array}{l}\text { Sumber } \\
\text { Variasi }\end{array}$ & df & SS & MS & F \\
\hline Regresi & 3 & 990.2 & 330.1 & 1.15 \\
\hline Residual & 32 & 9188.7 & 287.1 & \\
\hline Total & 35 & 10179.0 & & \\
\hline
\end{tabular}

\section{2) Independen (Autokorelasi)}

Secara umum, pengujian autokorelasi menggunakan plot ACF seperti pada Gambar 8. Karena tidak ada lag yang keluar dari garis merah, maka dapat disimpulkan bahwa tidak terdapat autokorelasi.

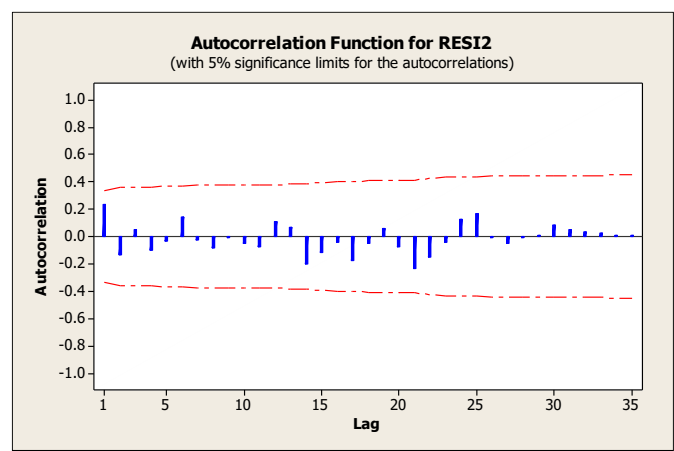

Gambar 8. Plot ACF Residual 2

3) Uji Normalitas

Hasil pengolahan minitab menggunakan test Kolmogorov Smirnov pada Gambar 9 menunjukkan $p$-value $>0,05$ sehingga sudah memenuhi asumsi normal.

4) Multikolinearitas

Dari hasil analisis regresi pada Tabel 6, nilai VIF $<5$ sehingga tidak ada multikolinearitas antar variabel bebas tersebut.

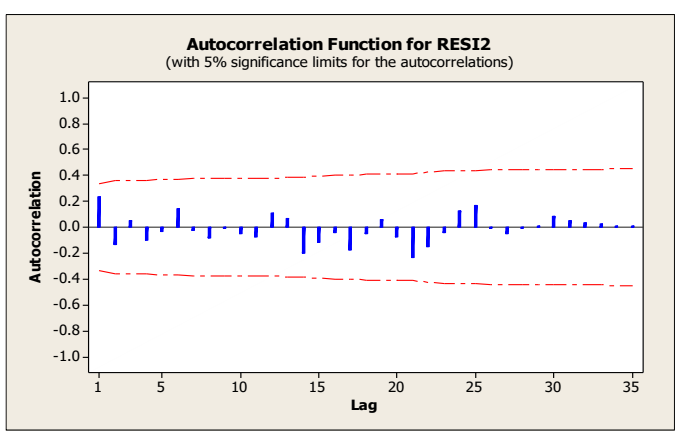

Gambar 9 Uji Normalitas Residual 2

Karena dari keempat asumsi residual yang ada semuanya terpenuhi sehingga model pada persamaan regresi pada persamaan (3) dapat digunakan untuk meramalkan model jumlah penangkapan ikan laut di Provinsi Jawa Timur. Dilihat dari Tabel 6, didapat nilai $R^{2}$ sebesar $89.3 \%$. Nilai $R^{2}$ ini berguna untuk mengetahui seberapa besar pengaruh dari variabel bebas terhadap variabel terikatnya. Semakin besar nilai $R^{2}$, semakin baik model regresi yang diperoleh. Nilai $R^{2}$ dari penelitian adalah sebesar 0,893 , hal ini berarti variabel $X_{1}$ yaitu nelayan, variabel $X_{2}$ yaitu motor boat penangkapan ikan dan variabel $X_{3}$ yaitu alat penangkapan ikan memengaruhi penangkapan ikan laut sebesar $89.3 \%$. Sedangkan sisanya sebesar $10.7 \%$.

\section{KESIMPULAN}

Model terbaik penangkapan ikan laut di Provinsi Jawa Timur tahun 1980-2016 setelah dilakukan pemilihan model terbaik berdasarkan kriteria yang ada dengan metode regresi linier berganda dengan menggunakan transformasi Box-Cox adalah sebagai berikut:

$Y^{*}=420+0.000000 X 1^{*}+38.2 X 2^{*}-19.9$ $X 3 *+\varepsilon_{\mathrm{i}}$

dengan:

$Y_{i}^{*}$ mempunyai nilai $\left(Y_{l i}\right)^{0,5}$

$X_{1 i} *$ mempunyai nilai $\left(X_{I i}\right)^{2}$

$X_{2 i} *$ mempunyai nilai In $X_{2}$

$X_{3 i} *$ mempunyai nilai $\operatorname{In} X_{3 i}$

Besar sumbangan variabel bebasnya terhadap variabel responnya adalah $89.3 \%$ 


\section{DAFTAR PUSTAKA}

Brockwell, P. J. dan Davis, R. A. (2016) Introduction to Time Series and Forecasting. 3 ed. Basel: Springer International Publishing Switzerland.

Corder, G. W. dan Foreman, D. I. (2014) Nonparametric Statistics: A Step-by-Step Approach. 2 ed. New Jersey: John Wiley \& Sons.

Fox, J. (2016) Applied Regression Analysis and Generalized Linear Models. 3 ed. California: Sage Publication Inc.

Ghani, I. M. M. dan Ahmad, S. (2010) "Stepwise Multiple Regression Method to Forecast Fish Landing," Procedia Social and Behavioral Sciences, 8, hal. 549-554. doi: 10.1016/j.sbspro.2010.12.076.

Hyndman, R. J. dan Athanasopoulos, G. (2014) Forecasting Principles and Practice. Otexts.com.

Montgomery, D. C., Jennings, C. L. dan Kulahci, M. (2016) Introduction to Time Series Analysis and Forecasting. 2 ed. New Jersey: John Wiley \& Sons.

Situmorang, D. H. (2010) Pengaruh Peralatan Penangkap Ikan yang Digunakan terhadap Pendapatan Kepala Keluarga Nelayan di Kelurahan Kangkung Kecamatan Telukbetung Selatan Kota Bandar Lampung Tahun 2009. Universitas Lampung.

Sudirman dan Mallawa, A. (2004) Teknik Penangkapan Ikan. Jakarta: Rineka Cipta.

Sulistiyanti dan Wahyudi (2015) "Pengembangan Ekonomi Wilayah Berbasis Sektor Perikanan di Provinsi Jawa Timur," Media Trend, 10(2), hal. 140-164.

Welc, J. dan Esquerdo, P. J. R. (2018) Applied Regression Analysis for Business: Tools, Traps and Applications. Cham: Springer International Publishing AG. 